\title{
Infection Patterns of Helminth Parasites in Mackerel Tuna (Euthynnus affinis Cantor, 1849) from Banten Waters, Indonesia
}

\author{
Muhammad Raihan Pambudi ${ }^{1}$, Sulistiono1* ${ }^{*}$, Risa Tiuria², Sonja Kleinertz ${ }^{3,4}$ \\ ${ }^{1}$ Department of Aquatic Resources Management, Faculty of Fisheries and Marine Sciences, IPB University \\ 2Department of Animal Diseases and Veterinary Public Health, Faculty of Veterinary Science, IPB University \\ ${ }^{3}$ Faculty of Fisheries and Marine Sciences, IPB University \\ Jl. Agatis, Kampus IPB Dramaga, Bogor 16680, Indonesia \\ ${ }^{4}$ Aquaculture and Sea-Ranching, Faculty of Agricultural and Environmental Sciences, University of Rostock \\ Justus-von-Liebig-Weg 2, 18059 Rostock, Germany \\ Email: onosulistiono@gmail.com
}

\begin{abstract}
The study of zoonotic parasites is of extreme importance, because they can cause diseases in humans and can negatively impact the marketability of fisheries products. The present study aims to determine the infection patterns of helminth parasites infecting mackerel tuna in Banten waters, as well as to clarify possible negative impacts to its fish host. Mackerel tunas were caught from March to July 2020 in Banten Bay and Sunda Strait and obtained from Karangantu fishing port and Muara Angke fishing port. For parasite identification, different staining methods were used ( $\mathrm{KOH}$, Semichon's acetocarmine). Helminth parasites that has been found in this study belonged to the taxa of Monogenea (1), Digenea (1), Nematoda (2) and Acanthocephala (2). The helminth parasite species with the highest prevalence was Hexostoma euthynni (P: 16.7\%) from Banten Bay and Neorhadinorhynchus sp. (P: 53.3\%) from Sunda Strait followed by a possible zoonotic parasite Anisakis sp. with 46.7\% prevalence. In this study four new locality records were established. Pathogenic impacts from the isolated parasites to the examined fish could be expected, especially for the revealed $H$. euthynni, which may decrease the fish's ability to perform proper respiration, cause irritation to gills, and anemia. Preventive actions on anthropogenic activities will be required in order to keep the natural conditions in the areas of Banten Bay and Sunda Strait. Regular fish parasite monitorings will lead to the sustainable use of fisheries resources, assess possible fish health impacts, and zoogeographical distributions of zoonotic and pathogenic parasites.
\end{abstract}

Keywords: Anisakis, zoonoses, helminth parasites, mackerel tuna, pathogenic impacts

\section{Introduction}

According to Levine (1990) parasites are organisms that live on or inside other organisms (hosts). Helminths have adapted to live often as endoparasites within their hosts and have developed a variety of adaptations to attach themselves to them, like suckers and hooks, or produce lots of eggs in order to enhance their successful infection rates. Parasites can change its chemical properties to suit the host's body (Levine, 1990). Usually, there is more than one parasite in a single host, where they will interact. The diversity of fish parasites are expected to be high in this region due to Indonesia's tropical marine waters high biodiversity scenarios (Carpenter and Springer, 2005).

The abundance of helminth parasites can be influenced by biotic and abiotic factors and is highly dependent on the host (Rueckert et al., 2008). Ecology, migration, recruitment, and environmental conditions of the host are associated with their presence. Helminth parasites can infect fish at various trophic levels. Rohde (2005) demonstrated that temperature and water trophic level are two crucial environmental parameters affecting helminth parasites' presence. Infection from helminth parasites in mackerel tuna can result in ecological, economic, and biological impacts. In terms of ecological impact, Echinomermella matsi is an example of an helminth parasite that controls the abundance of its sea urchin host, thus affecting the entire ecosystem (Rohde, 2005). Parasites are also a serious problem to aquaculture due to their ability to decreases growth and increases mortality, thus the culture process will not succeed (El Madhi et al., 2015). According to Rohde (1984), some helminths like Acanthocephala may perforate the intestine, causing biological changes in their hosts.

Studies on helminth parasites in mackerel tuna revealed many species, including the muscle- 
infecting Didymozoon diverticulum Yamaguti, 1970 from Bay of Bengal (Madhavi and Sai Ram, 2000), Anisakis spp. from Pekalongan (Linayati and Madusari, 2019), and the zoonotic parasite Anisakis simplex from Aceh Besar (Hidayati et al., 2016). The study of zoonotic parasites is of extreme importance because they can cause diseases in humans and they can negatively impact the marketability of fisheries products (Malouf, 1986). Kleinertz et al. (2014) explained that fish parasites could be used as environmental bioindicators. The study by Rueckert et al. (2008) in Segara Anakan (Cilacap) showed that parasites are useful tools for monitoring of bacterial biomass, heavy metals, or other environmental stresses. Parasites can also be a potential biomarker for fish stock seperation, as shown in the study by Mattiucci et al. (2014), which compared marlin populations from the Mediterranean and Atlantic Seas.

Several research activities in Banten waters have been conducted, i.e., to clarify environmental water conditions (heavy metals in sediments) (Wardani et al., 2020), heavy metals in crabs (Febrianessa et al., 2020), and heavy metals in mud crabs (Noviani et al., 2020). However, information about occuring helminth parasites in fish (especially mackerel tuna) has not been reported from these region before. Even after the demonstration of Palm et al. (2017) that the distribution of Anisakis spp. in Indonesian waters revealed a low risk for (fish) foodborn anisakiasis, its necessary to perform regular monitorings due to shifting boundaries under global change scenarios in future. Regular endoparasite monitorings in commercially used fish species can support the risk assessment of zoonotic parasite distributions. Therefore, the high diversity of helminth parasites in this regions is an interesting subject to study in order to sustainably use our fisheries resources. The present study aims to evaluate the diversity of helminth parasites infecting mackerel tunas in Banten waters as well as shed light on the possible pathogenic impacts to their fish hosts and to possibly determine a correlation between helminth parasites with the fish's biological conditions and the environment, such as sea surface temperature and chlorophyll-a concentrations.

\section{Materials and Methods}

The research was conducted from March to October 2020. The number of samples taken was 30 freshly killed mackerel tunas from Pelabuhan Perikanan Nusantara (PPN) Karangantu and 15 freshly killed mackerel tunas from Pangkalan Pendaratan Ikan (PPI) Muara Angke. Due to a limited timeframe as well as access to sampling sites, replicates could not be taken. When possible, 30 specimens were sampled in order to represent the subpopulation. According to Jovani and Tella (2006), by measuring the prevalence data, uncertainty rapidly decreases with increases in sample sizes of up to 10-20 individuals, but not much more by further sizes of increasing samplings. A sample size of around 15 can be used as a reasonable trade-off between not losing too much data information from the analyses and to still maintain acceptable levels of uncertainty.

The collected fish were kept frozen separately in a plastic bag and inside a cool box and brought to Helminthology Laboratory, Faculty of Veterinary Science, IPB University. The samples were kept frozen at $-20^{\circ} \mathrm{C}$ until further examination. Fish samples were defrosted in lukewarm water. The total length and total weight of each fish were measured. Skin, fins, eyes, nostrils, mouth cavity, gills, and operculum were examined for ectoparasites. Gill arches were separated and placed in a petri dish with a saline solution $(\mathrm{NaCl}$ $0.9 \%$ ) and examined under the microscope. The body cavity, intestine, stomach, gonad, liver, heart, and gall bladder were examined for endoparasites. The organs were separated and placed in a petri dish filled with saline solution. The intestine and stomach were dissected to examine the inside, while other organs were pressed between two Petri dishes and placed under a microscope (Kleinertz et al., 2014).

Different staining methods were used for identification following the methods according to Indaryanto et al. (2014). The isolated helminth parasites were dehydrated in a graded ethanol series $(70 \%, 85 \%, 90 \%$, and absolute). $\mathrm{KOH}(10 \%)$ and clove oil were used for staining of the Nematoda and Acanthocephala, while Semichon's acetocarmine was used for staining Monogenea, Digenea, and Cestoda. Helminth parasites identification referred to Hendrix, (1994); Rohde, (1978); Arai and Smith, (2016); Liang-Sheng, (1960); Gibson, (1996); Amin, (1987); and Amin and Nahhas, (1994). Parasite calculations like prevalence, (mean) intensity and (mean) abundance were calculated following Bush et al. (1997). Prevalence and intensity were categorized according to Williams and Williams (1996).

The data of sea surface temperature and chlorophyll-a concentrations were obtained from oceancolor.gsfc.nasa.gov and processed using SeaDAS and Microsoft Excel. Parameters observed in this study included condition factor (K), prevalence $(P)$, intensity $(\mathrm{I})$, mean intensity $(\mathrm{ml})$, and mean abundance $(\mathrm{mA})$. Spearman's rank correlation was used to determine the correlation between the 
number of helminth parasites and the fish's condition factor, total length, total weight, sea surface temperature and chlorophyll-a.

\section{Results and Discussion}

\section{Parasite examinations and taxonomic characteristics}

This study revealed six different taxa of helminth parasites that infected the examined mackerel tunas, belonging to Monogenea (1), Digenea (1), Acanthocephala (2), and Nematoda (2) (Table 1). Neorhadinorhynchus sp. was the parasite genus with the highest prevalence from Sunda Strait, with an intensity of 1-154 individuals. A prevalence of $53.33 \%$ showed that this parasite frequently infect the mackerel tuna in the Sunda Strait and that the intermediate hosts of this parasite species are abundant in this area. Neorhadinorhynchus sp. is a member of the Acanthocephala and one of the endoparasites that infect the digestive organs of its hosts. It has an aspinose body with a proboscis armed with spines and four tubular cement glands (for more details, see Amin and Nahhas (1994)). On the contrary, only two Rhadinorhynchus sp. individuals were found in this study. This condition can be a result of competition between parasites infecting the same organs in the same hosts. There were no records of these Acanthocephalans infecting mackerel tunas from Sunda Strait at PPI Muara Angke, meaning that the present study is the first locality record for this parasite species in this region. Acanthocephala can damage its host's tissues. The damage can be severe depending on the size and shape of the proboscis (Rohde, 2005), penetrating sometimes deep into the host tissue.

Hexostoma euthynni is a monogenean ectoparasite infecting the gills. It is characterized by eight suckers on its opisthaptor, equipped with sclerites (two B-shaped and one X-shaped sclerite in the middle) on each sucker, differentiating it from other members of the genus (Rohde, 1978). The prevalence of $H$. euthynni in this study was $16.7 \%$ in mackerel tuna in Banten Bay, with an intensity of 12 individuals. This study is the first to record this monogenean in mackerel tuna from Banten Bay, resulting in a new locality record. Previously, $H$. euthynni has been found to infect fish in the genus Euthynnus from many seas (see Millemann, 1956; Rohde, 1978; and Justo and Kohn, 2015).

Only one genus of digenean parasites was revealed in this study, Lecithocladium sp. which was isolated from the stomach, with a prevalence of $13.3 \%$ and an intensity of 2-18 individuals. These species has two suckers (oral and ventral) with different functions. The oral sucker functions as a food tract, while the ventral sucker attaches parasite's the body to the host's organ (Rohde, 2005). In previous studies, Indaryanto et al. (2015) revealed the same genus but in chub mackerel from Banten Bay. This study was the first to record Lecithocladium sp. infecting mackerel tunas from Sunda Strait at PPI Muara Angke, leading to a new locality record. The helminth parasite with the lowest prevalence from Banten Bay was Camallanus sp., with only one revealed individual. This study showed that this parasite occasionally infects mackerel tunas from Banten Bay. This endoparasite was found in the intestine of the host (Hidayati et al., 2016). Camallanus sp. is characterized by a rounded mouth with shell-like valves, sclerotized, and a slit-like opening (for details, see Liang-Sheng, 1960). This study is the first to record Camallanus sp. infecting mackerel tunas from Banten Bay, leading to a new locality record. Ascaridoidea are a superfamily in the Nematoda, characterized by a non-segmented cylindrical and bilaterally symmetric body shape. The body is covered with cuticle layer with the anterior end split into three 'lips' (Arai and Smith, 2016). Due to the difficulty to morphologically identify Anisakis larvae to species level, the

Table 1. Isolated parasite taxa, given are prevalence $(\mathrm{P})$, intensity $(\mathrm{I})$, mean intensity $(\mathrm{ml})$ and mean abundance $(\mathrm{mA})$

\begin{tabular}{|c|c|c|c|c|c|c|c|c|}
\hline \multirow{2}{*}{ Parasite taxa } & \multicolumn{4}{|c|}{ Banten Bay } & \multicolumn{4}{|c|}{ Sunda Strait } \\
\hline & $\mathrm{P}(\%)$ & 1 & $\mathrm{ml}$ & $\mathrm{mA}$ & $\mathrm{P}(\%)$ & I & $\mathrm{ml}$ & $\mathrm{mA}$ \\
\hline Monogenea & & & & & & & & \\
\hline $\begin{array}{l}\text { Hexostoma euthynni } \\
\text { Digenea }\end{array}$ & 16.67 & $1-2$ & 1.60 & 0.27 & - & - & - & - \\
\hline $\begin{array}{l}\text { Lecithocladium sp. } \\
\text { Nematoda }\end{array}$ & - & - & - & - & 13.33 & $2-18$ & 10 & 1.33 \\
\hline Ascaridoidea & 16.67 & $1-2$ & 1.20 & 0.20 & 46.67 & $1-5$ & 2.14 & 1 \\
\hline Anisakis sp. & - & - & - & & 46.67 & $2-17$ & 8.14 & 5.18 \\
\hline $\begin{array}{l}\text { Camallanus sp. } \\
\text { Acanthocephala }\end{array}$ & 3.33 & 1 & 1 & 0.03 & - & - & - & - \\
\hline Neorhadinorhynchus sp. & - & - & - & - & 53.33 & $1-154$ & 40.13 & 1 \\
\hline Rhadinorhynchus sp. & - & - & - & - & 13.33 & 1 & 1 & 0.13 \\
\hline
\end{tabular}


specimens could not be further identified. There was a larva tooth on the anterior end with a mucron on the posterior end. The long ventricle was without any attachments (appendix or caecum). These endoparasites were found in the digestive tract of the mackerel tuna. Anisakis sp. in mackerel tuna has been found in previous studies (Hidayati et al., 2016; Linayati and Madusari, 2019). Some species from the genus Anisakis can be zoonotic if ingested by humans, causing anisakiasis with diarrhea, vomiting, and allergic reactions. The prevalence of Ascaridoidea showed that it often infects mackerel tunas from Banten Bay and commonly infecting mackerel tunas from Sunda Strait. Ascaridoidea could resemble Anisakis as well so we did not count it in the species richness as an extra nematode member. The overall prevalence and intensity of infection were higher in mackerel tunas from Sunda Strait. Many ecological and biological factors can lead to that shown results, including the host's food variety, life span, migration area, schooling, and body size (Rohde, 1984).

\section{Fish health impacts}

Monogenean like the isolated $H$. euthynni that infects the gills can lead to significant damage to the host's tissues, thus decreasing its host's ability to perform proper respiration (Suwignyo et al., 2005). Monogenans can cause problems especially to farmed fish. Conditions of fish culture, such as feeding foods with fewer nutrients than natural foods, low water quality, and being crowded together in high densities, will increase the monogenean's reproduction rate. The genus Hexostoma is one of the polyopisthocotyleans that can cause irritations to the gill tissures due to their clamps attaches over the gill's secondary lamellas (Rohde, 2005). Fish that are heavily infected by polyopisthocotylean parasites usually shows symptoms of anemia, including skinny body, loss of appetite, dark body color, and slow-swimming abilities (Ogawa, 2014).

Trematodes like Lecithocladium sp. that live in the digestive tract does not harm their host significantly because of their relatively small size compared to the host and their innocuous diet (Rohde, 2005). Though not seem to be a significant pathogens, Lecithocladium sp. are still known to cause gastro-intestinal tract hispathology in marine fishes (Indaryanto et al., 2015).

Along with many other nematodes, Camallanus sp. parasites can damage its host digestive tract (Hakim et al., 2019). Aggregation of L3-larvae and L4-larvae, and adult anisakids (including Anisakis sp.) is known to cause gastritis in their host. Hosts sometimes have necrosis of different inner organs, such as the liver, lesions, and can show severe depletion of lipids. Heavy infections shows symptoms, such as diarrhea, anemia, dehydration, and can lead to increased mortalities (Klimpel and Palm, 2011).

In terms of the two isolated acanthocephalans, some negative effects will be expected to occur in their fish host. Rhadinorhynchus sp. with their long proboscis that penetrate the fish's intenstine deeply can lead to inflammatory nodules (El Madhi et al. 2015). Damage caused by acanthocephalans can change the structure of intestinal tissues such as degradation of villi, which will significantly affect the efficiency of the host's digestion and absorption process (Sanil et al., 2011). Other effects caused by acanthocephalans can be progressive weightloss and disproportion of the head to the body size, but these rarely leads to mortality (Valladão et al., 2019).

Table 2 Possible negative health impacts from the isolated parasites

\begin{tabular}{|c|c|c|}
\hline Parasites & Health Impact on the Host & Citation \\
\hline Hexostoma euthynni & Decrease host's ability to do respiration, irritation, and anemia & $\begin{array}{l}\text { Suwignyo et al. (2005), Rohde } \\
\text { (2005), Ogawa (2014) }\end{array}$ \\
\hline Lecithocladium sp. & Gastro-intestinal tract hispathology & Indaryanto et al. (2015) \\
\hline Anisakis sp. & $\begin{array}{l}\text { Gastritis and necrosis of different inner organs. Heavy } \\
\text { infections may cause diarrhea, anemia, and dehydration. }\end{array}$ & Klimpel and Palm (2011) \\
\hline Camallanus sp. & Damage the host's digestive tract & Hakim et al. (2019) \\
\hline $\begin{array}{l}\text { Rhadinorhynchus sp. and } \\
\text { Neorhadinorhynchus sp. }\end{array}$ & $\begin{array}{l}\text { Form inflammatory nodules in the host's intestine, } \\
\text { degradation of villi, progressive weightloss, body and head } \\
\text { size disproportion. }\end{array}$ & $\begin{array}{l}\text { Sanil et al. (2011), El Madhi et } \\
\text { al. (2015), Valladão et al. } \\
\text { (2019) }\end{array}$ \\
\hline
\end{tabular}

Table 3. Sea surface temperature and chlorophyll-a from both locations

\begin{tabular}{lcc}
\hline \multicolumn{1}{c}{ Parameter } & \multicolumn{2}{c}{ Range and Average } \\
\cline { 2 - 3 } & Banten Bay & Sunda Strait \\
\hline Sea surface temperature $\left({ }^{\circ} \mathrm{C}\right)$ & $29.9-32.6(30.2 \pm 0.213)$ & $29.8-30.8(29.9 \pm 0.102)$ \\
Chlorophyll-a $\left(\mathrm{mg} \cdot \mathrm{m}^{-3}\right)$ & $0.6-3.0(1.3 \pm 0.799)$ & $0.5-4.7(1.1 \pm 0.763)$ \\
\hline
\end{tabular}




\section{Correlation analysis}

Environmental conditions can also affect the number of parasites (Rueckert et al., 2008). Sea surface temperature and chlorophyll-a can be seen in Table 3. The average condition factor for mackerel tuna from Banten Bay was $1.4433 \pm 0.091$, while that for the Sunda Strait was $1.550 \pm 0.286$. There was no correlation detected between the number of helminth parasites and the average condition factor in this study (Sunda Strait's $r_{s}=0.0143$; Banten Bay's $\left.r_{s}=0.1000\right)$. This result may be caused by the prevalence of helminth parasites below 90-100\%, which is the range of prevalence where significant damage can happen to the host. The average condition factor from both locations was more than 1 , showing that the mackerel tunas were in "plump" condition (Arifah et al., 2015). According to Wudji et al. (2012), plump fishes tends to have a condition factor range of 1-3, while less plump fishes have a condition factor range of 2-4. Condition factor values that are more than 1 may indicate that the fish have plenty of foods and lives in an environment with good conditions (Agustina et al., 2018).

Mackerel tunas from Sunda Strait were 36.1$38.7 \mathrm{~cm}$ in length, while those from Banten Bay were $20.6-25.0 \mathrm{~cm}$. The results showed an increase in the number of parasites with the fish's total length. Madhavi and Sai Ram (2000) showed that mackerel tunas with less than $30 \mathrm{~cm}$ in length had a lower average prevalence and infection intensity of parasites. Rohde (1984) also explained that larger fish tended to have a more diverse diet, increasing the chance of interaction with the parasites and accumulation of endoparasites over time. Usually the larger the fish is the older it can be considered. This results in an increasing parasitation and accumulation, especially for food web dependent endoparasites. Thus they have more time to accumulate parasites (Santos-Bustos et al., 2020).

In contrast, the correlation analysis showed that there was no correlation between the number of parasites, total length (Sunda Strait's $r_{\mathrm{s}}=0.0275$; Banten Bay's $r_{\mathrm{s}}=-0.0958$ ), and total weight (Sunda Strait's $r_{s}=-0.1220$; Banten Bay's $r_{s}=0.1333$ ) of the examined fish in the present study. Despite that, it is more common for increased parasite infections in larger and older fish (Rohde 1984). This result may be caused by other environmental factors of each location, affecting the number of parasites instead of the fish's total length or total weight.

The correlation analysis in this study also showed no correlation between sea surface temperature and chlorophyll-a with the abundance of parasites from both locations ( $\left.r_{s}=0.5033\right)$. Differences in sea surface temperature and chlorophyll-a were not too distinct. Thus, other water quality parameters not observed in this study may have affected the helminth parasites at both locations. This result could also be caused by the stable tropical conditions (Indaryanto et al., 2014).

The average temperature at both locations did not exceed the standard for living organisms that lives in that environment (Indonesian Ministry of Environment, 2004), though the average temperature at Banten Bay was slightly higher than Sunda Strait. Higher temperatures can increase the abundance of Nematoda, Digenea (Rohde, 2005), and Acanthocephala (Hassanine, 2006). According to Macnab and Barber (2011), high temperature can result in the occurrence of helminth parasites with higher metabolism and growth rates. This condition may also lead to faster reproduction of the parasites. The host's immunity system against the parasites can on the other hand be compromised under higher temperatures.

The value of chlorophyll-a can determine the trophic water level. Waters with chlorophyll-a $<1$ mg. $\mathrm{m}^{-3}$ are categorized as oligotrophic, $\geq 1-3 \mathrm{mg} \cdot \mathrm{m}^{-3}$ are categorized as mesotrophic, $\geq 3-5 \mathrm{mg} \cdot \mathrm{m}^{-3}$ are categorized as eutrophic, and $>5 \mathrm{mg} \cdot \mathrm{m}^{-3}$ are categorized as hypereutrophic (Irawati, 2014). Thus, both Banten Bay and Sunda Strait were mesotrophic. According to Budria (2017), eutrophication can increase the number of parasites by affecting the phytoplankton and the composition of food webs. Thus more organisms will live in the environment. This conditions will increase the chance of parasites to find their hosts and complete their life cycles.

Members of the Ascaridoidea (Nematoda) have an indirect life cycle using copepods, small fishes, larger fishes, and cephalopods as their intermediate hosts (Klimpel and Palm, 2011). Tremadodes like Lecithocladium sp. need molluscs as their intermediate host, and acanthocephalans need small invertebrates like crustaceans (Rohde, 1993, 2005). Endohelminth parasites are known to be directly connected to their intermediate hosts and transmitted via the food chain. Mackerel tunas are opportunistic carnivores feeding on small fishes, shrimps, and cephalopods (Collette and Nauen, 1983), which explains the accumulation of these different endoparasites by their diet.

In contrast to endoparasitic taxa, ectoparasitic monogeneans usually have a direct life cycle without intermediate hosts. This fact lead to high infestation patterns, especially under culture conditions of fish where the usually host specific monogeneans can spread easily from one host to the other (Rohde, 1993). 
For example, $H$. euthynni and many other monogeneans depend on water currents, light, and chemicals to find their hosts. With an area of $10 \mathrm{x}$ $15 \mathrm{~km}$ and a shallow depth of $<20 \mathrm{~m}$ (Febrianessa et al., 2020), Banten Bay will likely have fewer strong currents. However, more pollutants may be accumulated due to intense industrial activities (Wisha et al., 2015). H. euthynni can still survive even under this condition, which can be explained by many ectoparasites high adaptive ability to environmental stress (Sures, 2008).According to Ardelia et al. (2016), mackerel tunas also have multispecies schooling behaviour, often with other Scombridae fishes like yellow-fin tuna. A school of mackerel tunas consists of 100-5,000 individuals. This behaviour, along with their migration, can increase the chance of being infected by the parasites, especially ectoparasite which can easily be transmitted to each member of the same fish population. As the fish migrates, there is a chance of passing through certain areas with abundant and infected intermediate hosts, leading to a broad zoogeographical distribution range of these parasites.

\section{Conclusion}

The infection patterns of the helminth parasites that infected mackerel tunas at Banten Bay were different from those at Sunda Strait. These differences can be a result of differences in the environmental conditions, food availability, fish ecology or other related factors. It is also possible that some differences are due to the different sampling sizes of examined fish (15 vs. 30). According to Jovani and Tella (2006), a sample size of around 15 can be used as a reasonable trade-off between not losing too much data information and to maintain acceptable levels of uncertainty.

The isolated helminth parasites in this study belonged to the taxa of Monogenea, Digenea, Nematoda and Acanthocephala. The helminth parasites with highest prevalence, intensity, and abundance were Hexostoma euthynni from Banten Bay and Neorhadinorhynchus sp. from Sunda Strait. In this study four new locality records were established. The number of parasites in this study was not correlated with the fish's condition factor, total length, and total weight, nor sea surface temperature and chlorophyll-a. Pathogenic impacts from isolated parasites to the examined mackerel tuna could be expected especially for the revealed Hexostoma euthynni, which may decrease the mackerel tuna's ability to do respiration, cause irritation, and anemia. Comprehensive management is needed to control helminth parasites in the wild. Preventive actions on anthropogenic activities will be required, so the areas of Banten Bay and Sunda
Strait can keep their natural conditions. Studies on mackerel tunas' stomach content from these waters can also help to enhance the knowledge about occurring helminth parasites, intermediate hosts and to clarify possible transmission pathways. Regular fish parasite monitorings are necessary for valuable and commercially used fish species in order to enhance fish health status and management. This will lead to a sustainable use of fisheries resources in this area and will also help to assess possible fish health impacts and the zoogeographical distribution of zoonotic parasites, especially under changing environmental conditions.

\section{References}

Agustina, M., Jatmiko, I. \& Sulistyaningsih, R.K. 2018. Growth pattern and condition factor of kawakawa, Euthynnus affinis (Cantor 1849) in Tanjung Luar Waters West Nusa Tenggara. BAWAL. 10(3):179-185. doi: 10.15578/bawal. 10.3.2018.179-185.

Amin, O.M. 1987. Key to the Families and Subfamilies of Acanthocephala, with the Erection of a New Class (Polyacanthocephala) and a New Order (Polyacanthorhynchida). The J. Parasitol., 73(6):1216-1219. doi: 10.2307/32 82307.

Amin, O.M \& Nahhas, F.M. 1994. Acanthocephala of Marine Fishes Off Fiji Islands, with the Descriptions of Filisoma longecementglandatus n. sp., Neorhadinorhynchus macrospinosus n. sp. (Cavisomidae), and Gravid Females of Rhadinorhynchus johnstoni (Rhadinorhynchidae); and Keys to Species of the Genera Filisoma and Neorhadinorhynchus. J. Parasitol. 80(5): 768-774. doi: 10.2307/32 83256.

Arai, H.P. \& Smith, J.W. 2016. Guide to the Parasites of Fishes of Canada Part V: Nematoda. Magnolia Press. Auckland.

Ardelia, V., Vitner, Y. \& Boer, M. 2016 Biologi Reproduksi Ikan Tongkol Euthynnus affinis di Perairan Selat Sunda. J. IImu dan Teknol. Kelautan Tropis. 8(2):689-700. doi: 10.29244 /jitkt.v8i2.

Budria, A. 2017. Beyond troubled waters: the influence of eutrophication on host-parasite interactions. Funct. Ecol., 31:1348-1358. doi: 10.1111/1365-2435.12 880.

Bush, A.O, Lafferty, K.D, Lotz, J.M \& Shostak, A.W. 1997. Parasitology meets ecology on its own terms: Margolis et al. revisited. J. Parasitol. 83:575-583. 
Carpenter, K.E.\& Springer, V.G. 2005. The center of the center of marine shore fish biodiversity: the Philippine Islands. Environ. Biol. Fish., 72:467480.

Collette, B.B. \& Nauen, C.E. 1983. Scombrids of the World. An Annotated and Illustrated Catalogue of Tunas, Mackerels, Bonitos, and Related Species Known to Date. FAO Fish. Synop. 125(2):32-34.

El Madhi, Y., Darif, H., Hassouni, T., Lamri, D., Belghyti, D., Elkharrim, Kh., Chiahou, B., Barkia, H., Lamrioui, D. \& El Halouani, H. 2015. Helminths parasites of pompano, Trachinotus ovatus (L, 1758), from the harbor of Cap Water or Ras El Ma (Mediterranean Coast of Morocco). Int. J. Agric. Sci. Res. 4(4):82-85.

Febrianessa, N., Sulistiono, Samosir, A.M. \& Yokota, M. 2020. Heavy Metal ( $\mathrm{Pb}, \mathrm{Hg}$ ) Contained in Blue Swimming Crab (Portunus pelagicus Linnaeus, 1758) in Cengkok Coastal Waters, Banten Bay, Indonesia. IImu Kelautan: Indonesian Journal of Marine Science, 25(4): 157-164. doi: 10.14710/ik. ijms.25.4. 157164.

Gibson, D.I. 1996. Guide to the Parasites of Fishes of Canada Part IV: Trematoda. NRC Research Press. Ottawa.

Hakim, L.N., Irawan, H. \& Wulandari, R. 2019. Identifikasi Intensitas dan Prevalensi Endoparasit pada Ikan Bawal Bintang Trachinotus blochii di Budidaya Kota Tanjungpinang. Intek Akuakultur. 3(1): 45-55. doi: 10.31629/intek.v3i1.1005.

Hassanine, R.M.E. 2006. Acanthocephalans from Red Sea fishes. Family Cavisomidae Meyer, 1932: The Seasonal cycle of Diplosentis nudus (Harda, 1938) Pichelin et Cribb, 2001 in a Definitive Fish Host, and a Comment on Scerocollum Schmidt et Paperna, 1978. Acta Parasitologica. 51(2): 123-129.

Hendrix, S.S. 1994. Marine Floral and Fauna of the Eastern United States Platyhelminthes: Monogenea. NOAA Technical Report NMFS 121.

Hidayati, N., Bakri, M., Rusli, Fahrimal, Y., Hambal, M. \& Daud, R. 2016. Identifikasi Parasit pada Ikan Tongkol (Euthynnus affinis) di Tempat Pelelangan Ikan Lhoknga Aceh Besar. J. Medika Veterinaria. 10(1):5-8. doi: 10.21157/j.med. vet.v10i1.
Indaryanto, F.R., Wardiatno, Y. \& Tiuria, R. 2014. Struktur Komunitas Cacing Parasitik pada Ikan Kembung (Ratrelliger spp.) di Perairan Teluk Banten dan Pelabuhan Ratu. J. Ilmu Pertani. Indo., 19(1): 1-8.

Indaryanto, F.R., Abdullah, M.F., Wardiatno, Y., Tiuria R. \& Imai, H., 2015. A Description of Lecithocladium angustiovum (Digenea: Hemiuridae) in Short Mackerel, Rastrelliger brachysoma (Scombridae), of Indonesia. Tropical Life Sci. Res., 26(1): 31-40.

Indonesian Ministry of Environment. 2004. Keputusan Menteri Negara Lingkungan Hidup Nomor 51 Tahun 2004 tentang Baku Mutu Air Laut. Kementerian Lingkungan Hidup. Jakarta.

Irawati, N. 2014. Pendugaan Kesuburan Perairan Berdasarkan Sebaran Nutrien dan Klorofil-a di Teluk Kendari Sulawesi Tenggara. Aquasains. 3(1): 193-199.

Jovani, R. \& Tella, J.L. 2006. Parasite prevalence and sample size: Misconceptions and solutions. Trends in parasitology. 22: 214-218. doi.org /10.1016/j.pt.2006.02.011.

Justo, M.C.N. \& Kohn, A. 2015. Diversity of Monogenoidea Parasitizing Scombrid Fishes from Rio de Janeiro Coast, Brazil. J. Biodiv. Data. 11(3): 1-7. doi: 10.15560/11.3.1628.

Kleinertz, S., Damriyasa, I.M., Hagen, Y., Theisen, S. \& Palm, H.W. 2014 An Environmental Assessment of the Parasite Fauna of the Reefassociated Grouper Epinephelus areolatus from Indonesian Water. J. Helminthol., 88(2014): 50-63. doi: 10.1017/S0022149X12000715.

Klimpel, S. \& Palm, H.W. 2011. Anisakid Nematode (Ascaridoidea) Life Cycles and Distribution: Increasing Zoonotic Potential in the Time of Climate Change? Prog. Parasitol. 201-222. doi: 10.1007/978-3-642-21396-0.

Levine, N.D. 1990. Buku Pelajaran Parasitologi Veteriner. Gadjah Mada University Press. Yogyakarta.

Liang-Sheng, Y. 1960. On a Reconstruction of the Genus Camallanus Railliet and Henry, 1915. Journal of Helminthology. 34: 117-124.

Linayati, L. \& Madusari, B.D. 2019. Prevalence and Distribution of Anisakis sp Worms in Internal Organs of Tuna (Euthynnus affinis) at Fish Auction in Pekalongan City. IOP Conf. Ser.: Earth Environ. Sci., 399: 1-6. doi: 10.1088/ 1755-1315/399/1/012109. 
Macnab, V. \& Barber, I. 2011. Some (Worms) Like it Hot: Fish Parasites Grow Faster in Warmer Water, and Alter Host Thermal Preferences. Global Change Biol., 18(5): 1540-1548. doi: 10.1111/j.1365-2486.2011.02595.x.

Madhavi, R. \& Sai Ram, B.K., 2000. Community Structure of Helminth Parasites of the Tuna, Euthynnus affinis, from the Visakhapatnam Coast, Bay of Bengal. J. Helminthol., 74: 337-342.

Malouf, A.H. 1986. Report of the Royal Commission on Seals and Sealing in Canada, Vol. 3 Ottawa, Ontario.

Mattiucci, S., Garcia, A., Cipriani, P., Santos, M.N., Nascetti, G. \& Cimmaruta, R., 2014. Metazoan Parasite Infection in the Swordfish, Xiphias gladius, from the Mediterranian Sea and Comparison with Atlantic Populations: Implications for its Stock Characterization. Parasite. 21(35): 1-12. doi: 10.1051/parasite/ 2014036.

Millemann, R.E. 1956. Notes on the Genus Hexostoma (Monogenea: Hexostomatidae) with a Rediscription of $H$. euthynni Meserve, 1938. J. Parasitol., 42(3): 316-319.

Noviani, E., Sulistiono \& A.M. Samosir. 2020. Heavy Metal (Pb, Hg) Extent in Mud Crab (Scylla serrata) in Cengkok Coastal Waters, Banten Bay, Indonesia. Omni-Akuatika, 16(2): 108115. doi: 10.20884/1.oa.2020.16.2.810.

Ogawa, K. 2014. Diseases of cultured marine fishes caused by Platyhelminthes (Monogenea, Digenea, Cestoda). Parasitology. 14(1): 178195. doi: $10.1017 / \mathrm{s} 0031182014000808$.

Rueckert, S., Hagen, W., Yuniar, A.T. \& Palm, H.W. 2008. Metazoan Fish Parasites of Segara Anakan Lagoon, Indonesia, and Their Potential Use as Biological Indicators. Reg. Environ. Change. 9(4): 315-328 doi: 10.1007/s10113008-0076-2.

Rohde, K. 1978. Monogenea of Australian marine fishes. The genere Dionchus, Sibtrema, and Hexostoma. Publ. Seto Mar. Biol. Lab., 24(4-6): 349-367.

Rohde, K. 1984. Ecology of Marine Parasites. Helgoländer Meeresunters. 37: 5-33.

Rohde, K. 1993. Ecology of Marine Parasites an Introduction to Marine Parasitology. CAB International. Wallingford.

Rohde, K. 2005. Marine Parasitology. CSIRO Publishing. Collingwood.
Sanil, N.K., Asokan, P.K., John, L. \& Vijayan, K.K. 2011. Pathological manifestations of the acanthocephalan parasite, Tenuiproboscis $\mathrm{sp}$. in the mangrove red snapper (Lutjanus argentimaculatus) (Forsskål, 1775), a candidate species for aquaculture from Southern India. Aquaculture. 310(3-4): 259266. doi: 10.1016/j.aquaculture.2010.10.027.

Santos-Bustos, N.G., Violante-González, J., Monks, S., Rojas-Herrera, A.A., Flores-Rodríguez, P., Rosas-Acevedo, J.L. \& Villalba-Vasquez, P.J., 2020. Parasite Communities of Striped Bonito Sarda orientalis (Pisces: Scombridae) on the Pacific Coast of Mexico. N. Z. J. Zool., 48(2): 1 16. doi: 10.1080/03014223.2020.1792516.

Sures, B. 2008. Interactions between Parasites and Pollutants in the Aquatic Environment. Environ. Parasitol., 15(3): 434-438.

Suwignyo, S., Widigdo, B., Wardiatno, Y. \& Krisanti, M. 2005. Avertebrata Air Jilid I. Penebar Swadaya. Jakarta.

Valladão, G.M.R., Gallani, S.U., Jerônimo, G.T. \& de Seixas, A.T. 2019. Challenges in the control of acanthocephalosis in aquaculture: special emphasis on Neoechinorhynchus buttnerae. Reviews in Aquaculture. 12(3): 1-13. doi: $10.1111 /$ raq. 12386

Wardani, N.K., Prartono, T., \& Sulistiono. 2020. Sediments quality based on geo-accumulation index in heavy metals ( $\mathrm{Pb}, \mathrm{Cu}$, And $\mathrm{Cd}$ ) of Cengkok Coastal Waters, Banten Bay. J. Pendidikan IPA Indonesia. 9(4): 574-582. doi: 10.15294/jpnii.v9i4.24908.

Williams, E.H. \& Williams, L.B. 1996. Parasites of Offshore Big Game Fishes of Puerto Rico and the Western Atlantic. Department of Natural and Environmental Resources. Puerto Rico.

Wisha, U.J., Husrin, S. \& Prihantono. J. 2015. Hidrodinamika Perairan Teluk Banten pada Musim Peralihan (Agustus-September). IImu Kelautan: Indonesian Journal of Marine Science, 20(2): 101-112. doi: 10.14710/ ik.ijms.20.2.101-112.

Wudji, A., Suwarso \& Wudianto. 2012. Length-weight relationship, condition factors and sie structure of bali sardinella (Sardinella lemuru Bleeker, 1853) in Bali Strait Waters. BAWAL. 4(2):83-89. doi: 10.15578/bawal.4.2.2012.83-89 